\title{
Distribution of heavy metal concentrations in the different soft tissues of the freshwater snail Pomacea insularum (DOrbigny, 1839; Gastropoda), and sediments collected from polluted and unpolluted sites from Malaysia.
}

\begin{abstract}
Pomacea insularum were collected from polluted and unpolluted freshwater ecosystems in Malaysia. Besides the shells, the soft tissues were dissected and pooled into cephalic tentacle, foot, mantle, operculum, digestive tract, penial sac,lung sac, and remainder. These tissues were analyzed for the concentrations of $\mathrm{Cu}, \mathrm{Cd}, \mathrm{Fe}, \mathrm{Ni}$, and $\mathrm{Zn}$. The present work resulted in three interesting findings. First, the concentrations of $\mathrm{Cu}, \mathrm{Cd}, \mathrm{Fe}$, and $\mathrm{Zn}$ found in most of the different parts of P. insularum collected from the polluted Juru River were significantly (P50.05) higher than those found in the snails from the other four sites. Second, positive and significant correlation coefficients were found for sediment-lung sac for $\mathrm{Cd}, \mathrm{Fe}$, and $\mathrm{Zn}$ while sediment-digestive tract for $\mathrm{Cu}$. These correlation results indicated that lung sacs could reflect the environmental concentrations of $\mathrm{Cd}, \mathrm{Fe}$, and $\mathrm{Zn}$, while the digestive tract could do the same for $\mathrm{Cu}$. Third, the different concentrations of heavy metals found in the different parts indicated different metal regulation and binding sites in these organs. The significant correlation coefficients between different tissues indicated that they might be caused by similar metal regulation and sequestration. Based on the above findings, $\mathrm{P}$. insularum are a potential biomonitor of $\mathrm{Cd}, \mathrm{Cu}, \mathrm{Fe}$, and $\mathrm{Zn}$ pollution in freshwater ecosystems.
\end{abstract}

Keyword: Pomacea insularum; Heavy metals; Different soft tissues; Freshwater ecosystem. 